\title{
Canine ehrlichiosis: prevalence and epidemiology in northeast Brazil
}

\author{
Erliquiose canina: prevalência e epidemiologia no nordeste do Brasil \\ Paula Elisa Brandão Guedes ${ }^{1}$; Thais Nascimento de Andrade Oliveira ${ }^{1}$; Fábio Santos Carvalho²; \\ Renata Santiago Alberto Carlos ${ }^{3}$; George Rego Albuquerque ${ }^{3}$; Alexandre Dias Munhoz ${ }^{3}$; \\ Amauri Arias Wenceslau ${ }^{3}$; Fabiana Lessa Silva ${ }^{3 *}$
}

\begin{abstract}
${ }^{1}$ Programa de Pós-Graduação em Ciência Animal, Hospital Veterinário, Universidade Estadual de Santa Cruz - UESC, Campus Soane Nazaré de Andrade, Ilhéus, BA, Brasil

${ }^{2}$ Programa de Pós-Graduação em Genética e Biologia Molecular, Universidade Estadual de Santa Cruz - UESC, Ilhéus, BA, Brasil

${ }^{3}$ Departamento de Ciências Agrárias e Ambientais, Hospital Veterinário, Universidade Estadual de Santa Cruz - UESC, Campus Soane Nazaré de Andrade, Ilhéus, BA, Brasil
\end{abstract}

Received October 2, 2014

Accepted March 17, 2015

\begin{abstract}
Ehrlichiosis is a zoonotic disease that is caused by bacteria of the genus Ehrlichia. The aims of this study were to detect the presence of Ehrlichia spp. in the blood of dogs in Ituberá, Bahia, and to compare the sensitivities and specificities of blood smear, serological, and molecular examinations. Furthermore, this study identified factors associated with exposure to the agent in dogs in this locality. Blood samples were collected from 379 dogs and submitted for indirect immunofluorescent assay and polymerase chain reaction testing for the detection of Ehrlichia spp. antibodies and DNA, respectively. Additionally, a peripheral blood smear was obtained from the ear tip for parasite identification. Of the 379 animals, $12.4 \%, 32.7 \%$, and $25.6 \%$ were identified as positive on the blood smear, serological, and molecular tests, respectively. The dogs positive in one of the three techniques were considered exposed (46.9\%). Younger dogs and rural habitat were protective factors and presence of ticks and contact with other dogs were the risk factors associated with exposure to the agent. It was concluded that dogs of Ituberá have high positivity for Ehrlichia spp. and that the diagnostic methods used for detection are complementary.
\end{abstract}

Keywords: Diagnosis, dog, Ehrlichia canis, Indirect Immunofluorescence, nested PCR.

\section{Resumo}

Erliquiose é uma doença zoonótica causada por bactérias do gênero Ehrlichia. O objetivo desse estudo foi detectar a presença de Ehrlichia spp. no sangue de cáes em Ituberá-BA, e comparar as sensibilidades e especificidades do esfregaço sanguíneo, e testes sorológico e molecular. Além disso, esse estudo identificou fatores associados com a exposição ao agente em cães desta localidade. Amostras de sangue foram coletadas de 379 cães e submetidas à Reaçáo de Imunofluorescência Indireta e Reação em Cadeia de Polimerase para deteç̧ão de anticorpos e DNA de Ehrlichia spp., respectivamente. Adicionalmente, sangue periférico de ponta de orelha foi coletado para identificação do parasita. Dos 379 animais, 12,4\%, $32,7 \%$ e 25,6\% foram identificados como positivos no esfregaço sanguíneo, teste sorológico e molecular, respectivamente. Cães positivos em uma das três técnicas foram considerados expostos (46,9\%). Cães mais novos e hábitat rural foram fatores de proteção e presença de carrapatos e contato com outros cães foram os fatores de risco associados à exposição ao agente. Foi concluído que, os cáes do município de Ituberá têm alta positividade para Ehrlichia spp. e que os diferentes métodos diagnósticos utilizados para sua detecção são complementares.

Palavras-chave: Diagnóstico, cão, Ehrlichia canis, Imunofluorescência Indireta, nested PCR.

\footnotetext{
${ }^{*}$ Corresponding author: Fabiana Lessa Silva. Departamento de Ciências Agrárias e Ambientais, Hospital Veterinário, Universidade Estadual de Santa Cruz - UESC, Campus Soane Nazaré de Andrade, Rodovia Jorge Amado, Km 16, CEP 45662-900, Ilhéus, BA, Brasil.

e-mail: fabiana.lessa@gmail.com
} 


\section{Introduction}

Ehrlichiosis is an infectious disease that is caused by a gram-negative bacterium of the genus Ehrlichia, which includes species such as E. canis, E. chaffeensis, and E. ewingii and infects several animal species including humans (DUMLER et al., 2001; PEREZ et al., 2006). Canine monocytic ehrlichiosis is caused by $E$. canisand is transmitted by the tick vector Rhipicephalus sanguineus during its blood meal (AZEVEDO et al., 2011; DUMLER et al., 2001). This bacterium mainly parasitizes the cells of the mononuclear phagocyte system and causes clinical and hematological abnormalities such as fever, anorexia, vomiting, diarrhea, petechial hemorrhages, anemia, and thrombocytopenia (MOREIRA et al., 2003). Canine monocytic ehrlichiosis is found in many tropical and subtropical countries and is found in all regions of Brazil (AGUIAR et al., 2007; ALBERNAZ et al., 2007; AZEVEDO et al., 2011; CARLOS et al., 2007; CARVALHO et al., 2008; KRAWCZAK et al., 2012; MUNDIM et al., 2008; SILVA et al., 2010). Some factors may predispose dogs to disease development, such as older age, the presence of and contact with other dogs, living in urban habitats, and exposure to $R$. sanguineus parasitism (AZEVEDO et al., 2011; FAIERSTEIN et al., 2008).

A diagnosis of infection is based on the presence of inclusions or morulae in blood smears and on serological and/or molecular tests, in combination with clinical and hematological signs. Although the blood smear is the most frequently used diagnostic tool in veterinary medicine because of its convenience, serological and molecular tests are considered more sensitive (STEIN \& RAOULT, 1992; SUKSAWAT et al., 2000).

Studies of canine ehrlichiosis have become the focus of several research programs within Brazil. The increasing interest of researchers in conducting studies about this disease is due to the high morbidity and mortality of canine ehrlichiosis in Brazil. Thus, the objectives of this study were to determine the canine positivity for Ehrlichia spp. in the city of Ituberá, Bahia, and to identify possible risk factors associated with exposure to the agent that are currently unknown for this municipality.

\section{Materials and Methods}

\section{Location and animals of the study}

The study was conducted in the municipality of Ituberá in the south ofthe state of Bahia $\left(13^{\circ} 43^{\prime} \mathrm{S}, 39^{\circ} 08^{\prime} \mathrm{W}\right)$. The city has a total area of $417 \mathrm{~km}^{2}$, with approximately 26,591 inhabitants at a density of 71.5 inhabitants $/ \mathrm{km}^{2}$.

The study included a non-probabilistic sample of 379 domiciled adult dogs aged one year or older. The sample size calculation was performed using the Epi Info 3.5.3 software, with a confidence interval of $95 \%$ and the size of the dog population considered as $10 \%$ of the human population of the municipality (CIFUENTES, 1988). The sample collection was conducted between May and September 2012 and was distributed evenly throughout the neighborhoods of the city, covering both rural (56 animals) and urban $(323 \mathrm{dogs})$ areas. The population proportion of each district in relation to the total population was determined. For each house visited, a maximum of two dogs were evaluated. The Ethics Committee on Animal Use (CEUA/UESC) approved this study under protocol $n^{\circ} 028 / 12$.

\section{Epidemiological data collection}

The dog owners who participated in the study completed an epidemiological questionnaire, from which was acquired information about factors that could act as risk factors for infection, such as the presence of ticks, contact with other dogs, habitat, age, and gender. The dog owners were older than 18 years of age and, at the time of the visit, were responsible for the household. The questions were designed to identify risk factors for adog's exposure to Ehrlichia spp.and its vector in that locality.

\section{Collection of biological samples}

After the dogs were physically restrained, $8 \mathrm{~mL}$ of canine venous blood was collected by puncture of the jugular or cephalic vein. Five milliliters were dispensed into plastic tubes with an anticoagulant (EDTA), and $3 \mathrm{~mL}$ was dispensed into tubes without an anticoagulant. The tubes were placed in coolers with ice packs and sent to the Clinical Pathology Laboratory of the Veterinary Hospital of the State University of Santa Cruz. Additionally, peripheral ear-tip blood samples were collected by needle puncture $(30 \times 7 \mathrm{~mm})$, and one sample of each dog was prepared on a slide and stained with Giemsa for examination with optical microscopy.

\section{Serological and molecular tests and blood-smear examination}

Blood samples without EDTA were centrifuged to obtain serum, which was stored at $-20^{\circ} \mathrm{C}$. Subsequently, the detection of anti-E. canis antibodies was performed through indirect immunofluorescence assay (IFA) using silicate slides sensitized with E. canis (Jaboticabal strain)-infected DH82 cells. The reaction was adapted from that previously described by André et al. (2010), using an anti-dog conjugate (FITC F7884, Sigma ${ }^{\mathrm{TM}}$ ) and cutoff of 1:20. Samples that tested positive were subjected to serial dilutions in two basis until negativation. The negative and positive controls used for the dogs were canine sera on which serology had been performed in a prior study (CARLOS et al., 2007). The slides were observed under a UV light (BX51 Olympus microscope).

For polymerase chain reaction (PCR) testing, $3 \mathrm{~mL}$ of EDTA blood sample was processed for the extraction of DNA from the buffy coat by using an Easy-DNA kit (Invitrogen ${ }^{\circledR}$ ). The extracted DNA was stored at $-20^{\circ} \mathrm{C}$, and the DNA concentration in the samples was measured using a spectrophotometer (800 XI, FEMTO). For the first part of the DNA amplification, the ECC (5'-AGAACGAACGCTGGCGGCAAGC-3') andECB (5'-CGTATTACCGCGGCTGCTGGCA-3') primers were used. These primers amplified part of the 16S rRNA gene of Ehrlichia spp. Subsequently, to identify the species E. canis, the ECAN (5'-CAATTATTTATAGCCTCTGGCTATAGGA-3') and HE3 (5'-TATAGGTACCGTCATTATCTTCCCTAT-3') 
primers were used, following the methodology described by Murphy et al. (1998). The PCR products were subjected to electrophoresis on a $2 \%$ agarose gel containing ethidium bromide. The positive blood of a dog analyzed in a previous study by PCR (CARVALHO et al., 2008) was used as positive control, and the negative control was ultrapure water. Checking for the presence of the bands was performed with the aid of a transilluminator (Loccus Biotecnologia).

The blood smears were examined to detect Ehrlichia spp. inclusions or morulae by using optical microscopy (Primo Star, Zeiss).

\section{Statistical analyses}

To analyze the risk factors, all animals exposed to agent were considered (seropositives on IFA or positives on blood-smear examination or nested-PCR testing). Data obtained from the interviews were tabulated in the statistical package EPI INFO 3.5.1 (DEAN \& ARNER, 2009) and then analyzed by a chi-squared test along with the Yates correction or the Fisher exact test (SAMPAIO, 1998). The odds ratio (OR) of the bivariate analysis (explanatory variables versus the exposition to agent) was calculated using the measures of association and a 95\% confidence interval (CI). The variables with p values less than or equal to $20 \%$ and that showed biological plausibility were selected and subjected to the Spearman rank correlation test to determine collinearity ( $p \geq 0.8$ ) using the BIOESTAT 5.0 software. Non-conditional logistic regression was performed, with the final model created through the output variables of the system (backward). The comparison of sensitivity and specificity (ALTMAN \& BLAND, 1994 ) between techniques was performed using the program OpenEpi (DEAN et al., 2001), and the IFA was considered the gold standard test (VIEIRA et al., 2011).

\section{Results}

Ehrlichia spp. inclusions or morulae were observed in the blood smears of 47 (12.4\%) dogs. Serology (IFA) yielded positive results in $124(32.7 \%)$ dogs, with antibodies titers ranging from $1: 20$ (cutoff) to $1: 1280$. The nested-PCR test showed positive results in 97 (25.6\%) dogs. Of the positive animals, 20 (11.2\%) tested positive on blood-smear examination and IFA, 32 (17.9\%) on blood-smear examination and PCR testing, and 54 (30.3\%) on IFA and PCR testing, whereas 16 (8.9\%) dogs were identified as positive with all three techniques (Figure 1). Of the 379 study dogs, 178 (46.9\%) tested positive for Ehrlichia spp. with one of the three diagnostic techniques.

Compared with serology, the sensitivity and specificity of blood-smear examination were $16.13 \%(\mathrm{CI}=10.69-23.6 \%)$ and $89.41 \%(\mathrm{CI}=85.03-92.62 \%)$, and of nested PCR were $43.55 \%$ $(\mathrm{CI}=35.15-52.34 \%)$ and $83.14 \%(\mathrm{CI}=78.06-87.23 \%)$, respectively. Together, the three diagnostic techniques used in this study had low values of sensitivity and high values of specificity in all cases.

Results were compared between diagnostic techniques. On blood-smear examination and serology, 27 dogs were positive with the first technique and negative with the second, whereas

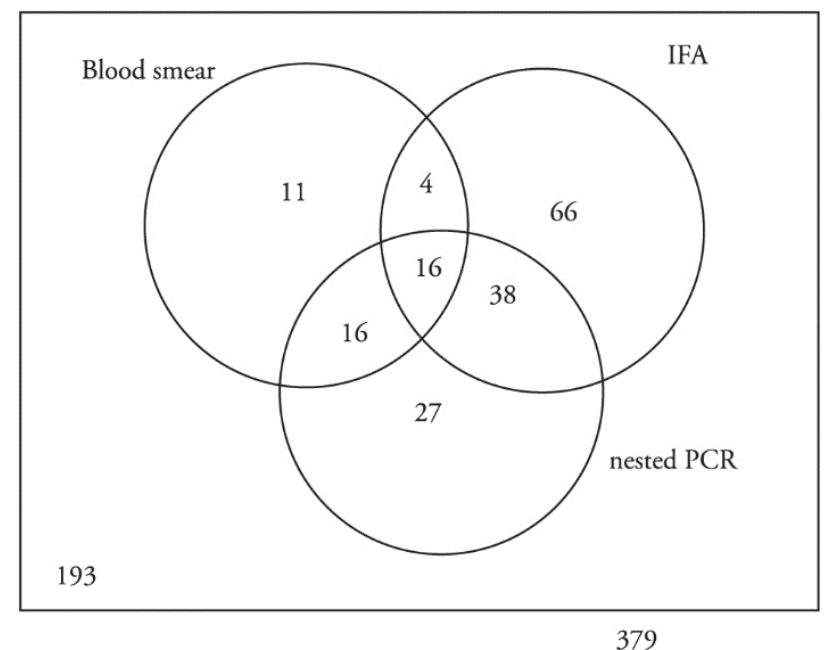

Figure 1. Results from the blood smear, IFA and nested PCR tests from the dog samples of Ituberá, BA.

104 animals were positive with the second technique and negative with the first (Figure 1). On blood-smear examination and nested-PCR testing, 15 animals tested positive withthe first test and negative with the second, whereas 65 dogs were identified as positive withthe second technique and negative with the first (Figure 1). On the IFA and nested-PCR test, 70 dogs were positive with the first diagnostic technique and negative with the second, whereas 43 dogs were positive with the second technique and negative with the first (Figure 1).

The factors associated with exposure to the agentof canine ehrlichiosis were age, habitat, contact with other dogs, and the presence of ticks. Dogs younger than four years of age and those living in rural areas were factors that protected a dog from exposure. Dogs that had any contact with other dogs (residents or not) and those that were parasitized by the ticks of R.sanguineus showed a higher predisposition to exposure (risk factors) (Tables 1 and 2).

\section{Discussion}

This study found that $12.4 \%$ of the canine blood-smear samples showed inclusions suggestive of Ehrlichia spp. Albernaz et al. (2007) and Moreira et al. (2003) found similar values (13.89\% and $15.97 \%$, respectively) in studies developed in the states of Rio de Janeiro and Minas Gerais. The first study was conducted using blood samples of pet dogs treated at the Veterinary Hospital of the State University of North Fluminense Darcy Ribeiro. The samples included in the study by Moreira et al. (2003) were obtained from dogs treated at the Veterinary Hospital of the Federal University of Minas Gerais with suspected hemoparasitoses. Diagnosis of Ehrlichia spp. infection by blood-smear examination depends on visualization of the morulae in leukocytes; hence, the sensitivity of this technique is usually low. Morulae in leukocytes are more abundant in the acute phase of the disease, and detection is more likely with higher parasitemia. Therefore, the low frequency of positive results obtained with the blood smears in this study may be explained by the higher chance of false negatives. However, 
Table 1. Factors associated with the of positive dogs to Ehrlichia spp.in the municipality of Ituberá, Bahia. Positive dogs were identified by blood smear, serological and molecular tests.

\begin{tabular}{|c|c|c|c|c|c|c|c|}
\hline \multicolumn{2}{|c|}{ Variable } & \multirow{2}{*}{$\frac{N}{142}$} & \multirow{2}{*}{$\frac{\text { Positive dogs }}{64}$} & \multirow{2}{*}{$\frac{\text { Prevalence }(\%)}{45.07}$} & \multirow{2}{*}{$\frac{\mathrm{OR}}{0.88}$} & \multirow{2}{*}{$\frac{95 \% \text { CI }}{0.58-1.34}$} & \multirow{2}{*}{$\frac{P \text {-value }}{0.64}$} \\
\hline Gender & Female & & & & & & \\
\hline & Male & 237 & 114 & 48.10 & $\mathbf{1}^{*}$ & & \\
\hline \multirow[t]{2}{*}{ Age (years) } & $1-4$ & 268 & 114 & 42.53 & 0.54 & $0.34-0.85$ & 0.01 \\
\hline & $>4$ & 111 & 64 & 57.65 & $1^{*}$ & & \\
\hline \multirow[t]{2}{*}{ Ticks } & Presence Ab- & 114 & 62 & 54.38 & 1.53 & $0.98-2.38$ & 0.07 \\
\hline & sence & 265 & 116 & 43.77 & $1^{*}$ & & \\
\hline \multirow[t]{2}{*}{ Habitat } & Rural & 56 & 18 & 32.14 & 0.48 & $0.29-0.88$ & 0.02 \\
\hline & Urban & 323 & 160 & 49,53 & $1^{*}$ & & \\
\hline Contact with & Yes & 280 & 138 & 49.28 & 1.43 & $0.90-2.28$ & 0.16 \\
\hline other dogs & No & 99 & 40 & 40.44 & $1^{*}$ & & \\
\hline Sleeping at & Yes & 94 & 48 & 51.06 & 1.24 & $0.78-1.98$ & 0.42 \\
\hline home & No & 285 & 130 & 45.61 & $1^{*}$ & & \\
\hline
\end{tabular}

* Reference.

Table 2. Association between positive dogs to Ehrlichia spp. and risk factors: age, presence of ticks, habitat and contact with other dogs in the municipality of Ituberá, Bahia.

\begin{tabular}{lccc}
\hline \multicolumn{1}{c}{ Variable } & Odds Ratio & $\begin{array}{c}\text { Confidence in- } \\
\text { terval at } 95 \%\end{array}$ & $\boldsymbol{P}$-value \\
\hline $\begin{array}{l}\text { Dogs younger } 4 \\
\text { years old }\end{array}$ & 0.53 & $0.33-0.84$ & 0.0076 \\
$\begin{array}{l}\text { Presence of } \\
\text { ticks }\end{array}$ & 1.72 & $1.08-2.72$ & 0.0211 \\
$\begin{array}{l}\text { Rural habitat } \\
\begin{array}{l}\text { Contact with } \\
\text { other dogs }\end{array}\end{array}$ & 0.39 & $0.20-0.73$ & 0.0038 \\
\hline $\begin{array}{l}\text { P= } 0.0716 \text { Likelihood=0.0002 } \\
\end{array}$ & $1.05-2.77$ & 0.0296 \\
\end{tabular}

false positives can also occur, because other structures may be mistaken for the morulae or inclusions of Ehrlichia spp.

(DAGNONE et al., 2009).

On IFA, the seroprevalence (32.7\%) found in this study was similar to the $35.6 \%$ prevalence reported by Souza et al. (2010). However, it was lower than the values found by Nakaghi et al. (2008) and Silva et al. (2010) of $63.3 \%$ and $42.5 \%$, respectively, in samples of domiciled domestic dogs from São Paulo and Mato Grosso. Souza et al. (2010) conducted their study in domiciled domestic dogs in the city of Salvador, only $150 \mathrm{~km}$ away from the city of Ituberá; the two sites may have similar climatic conditions for the maintenance of the vector and similar risk factors associated with the infection, which might explain the similar seroprevalence values found at the two sites. Nakaghi et al. (2008) conducted their research on blood samples obtained from dogs examined at the Veterinary Hospital of the University Paulista Julio de Mesquita Filho-Jaboticabal with clinical signs or hematological alterations suggestive of hemoparasitoses. This may explain the high seropositivity of these animals.

On the nested-PCR test, the DNA of E. canis was detected in $25.6 \%$ of the samples tested. This value was higher than the $11 \%$ and 7.8\% reported by Carlos et al. (2011) and Carvalho et al. (2008), respectively, who also conducted research in the southern region of Bahia. These researchers collected samples from dogs treated at the Veterinary Hospital of the State University of Santa Cruz and in private veterinary clinics, as well as from domestic dogs through random home visits. These results indicated that although the municipalities are near each other (approximately $200 \mathrm{~km}$ ) the rates of positivity for $E$. canis were quite different. One explanation for the difference among these values may be that the city of Ituberá lacks veterinary clinics and that public awareness of $E$. canis infection and the management of the disease and prophylactic care for dogs is lacking. In addition, the Ituberá dog population is predominantly semi-domiciled. Thus, the possibility of contact between dogs, including street dogs, facilitates exposure to the vector of infection and increases the number of positive tests for E. canis in this locality. In contrast, the animals studied by Carlos et al. (2011) and Carvalho et al. (2008) were domestic and had veterinary monitoring, which would have contributed to better animal health.

When comparing the sensitivity and specificity of the blood-smear and serologic techniques, we noted that the chances of false-negative results with the blood-smear technique were high, whereas the chances of false positives were low. However, authors assert that other structures can be confused with morulae of Ehrlichia spp. (DAGNONE et al., 2009), increasing the chances of false positives. The sensitivity of examination of the blood smear depends on the stage of infection of the animal at the time of the sampling. In the initial phase, when there is a higher parasitemia, there are more chances of finding infected leukocytes in the blood smear; however, in the subclinical and chronic phases of the disease, the chances of finding infected leukocytes decrease, which can result in false-negative results. However, the probability of detection of specific antibodies increases, because IFA detects anti-E.canis antibodies approximately 15 days after infection because of the time required to produce immunoglobulins (NAKAGHI et al., 2008; WANER et al., 2001). Furthermore, although the IFA is considered the gold standard technique, cross-reactions with other species from the genus Ehrlichia may occur (HARRUS \& WANER, 2011; VIEIRA et al., 2011).

The nested-PCR test identified 43 positive animals that did not have detectable levels of anti-E.canis antibodies in the serum. This finding may be explained by the fact that diagnosis by IFA is more effective in the advanced stages of the disease, 
with reduced sensitivity in the initial phase of infection leading to false negatives. The absence of $E$. canis DNA in 70 samples that were positive onserology might be explained by nonspecific reactions on serological testing causing false positives to $E$. canis (AL-ADHAMI et al., 2011). Furthermore, Ehrlichia spp. can parasitize splenic macrophages, and PCR testing is more sensitive with decreased chance of false-negative results when spleen samples are analyzed (HARRUS \& WANER, 2011), particularly in cases of chronic infection in which it is not always possible to detect the DNA of the agent in blood samples (HARRUS et al., 1998). Moreover, the sensitivity of molecular tests for Anaplasmataceae species can be increased with the use ofreal-time PCR testing (HARRUS \& WANER, 2011; SCHOTTHOEFER et al., 2013); however, it was not possible to perform this technique in this study. On IFA, cross-reactions can occur between species of the genus Ehrlichia, such as E. ewingii and E. chaffeensis. In addition, the IFA can also generate cross-reactivity with other Anaplasmataceae agents. Molecular studies indicate that new strains of Ehrlichia spp. and Anaplasma spp. may be present in wild carnivores (ANDRÉ et al., 2012.), cats (BRAGA et al., 2012; ANDRÉ et al., 2014), wild birds (MACHADO et al., 2012), and wild deer (MACHADO et al., 2006; SACCHI et al., 2012). These data indicate the possibility of agents showing similar genotypes to $E$. chaffeensis and E. canis being involved in the positivity of sampled dogs. Thus, there is need for further studies for confirmation. This may also explain the absence of detection of E. canis DNA in 15 samples in which morulae were visible, because the species of Ehrlichia cannot be identified on the blood smear (DAGNONE et al., 2009). In addition to the above mentioned points, because serological testing identifies only antibodies, a positive case on serology may appear negative on PCR testing because of eradication of the Ehrlichia organisms by the immune system. In this sense, the use of broad-based primers and then sequencing analysis of the positive samples for Ehrlichia sp. on PCR testing could clarify the possible involvement of species other than E. canis in seropositive dogs. However, this was not the focus of this research, which aimed to detect the DNA of only the E. canis species. Thus, the absence of sequencing analysis prevented better use and interpretation of results.

Of the 379 dogs evaluated, 16 had positive results with all of the diagnostic techniques, and 193 had negative results in all of them. Iqbal et al. (1994) compared the IFA and PCR techniques and concluded that the combination of techniques optimized the diagnosis. The results obtained in this study support the conclusion that the methods are complementary, because the different diagnostic techniques exhibited differences in the sensitivity and specificity for different stages of infection.

The risk factors associated with exposure to the agent in this study were corroborated by Azevedo et al. (2011) and Trapp et al. (2006), who found that increasing seropositivity frequency of dogs was directly related to increasing age. Therefore, young dogs may be protected from infection because older animals have greater contact time with the bacteria over the course of their lives (AZEVEDO et al., 2011).

Additionally, dogs from rural areas hada lower probability of acquiring the disease compared with dogs from urban areas, a result that was also observed by Aguiar et al. (2007). The occurrence of
$R$. sanguineus in urban areas is more frequent than in rural areas, where there is a predominance of ticks of the genus Amblyomma (COSTA et al., 2007), which consequently reduces the exposure of dogs from rural areas to the $E$. canis vector.

According to Azevedo et al. (2011), contact between dogs is a risk factor, as confirmed in this study. The transmission of ehrlichiosis by the tick vector requires the presence of an infected dog, so increased contact between dogs increases the chances of exposure to a tick vector infected with $E$. canis. Parasitism by ticks has also been shown to be a risk factor for infection (CARLOS et al., 2011; COSTA et al., 2007; TRAPP et al., 2006). This result is expected because $R$. sanguineus is the vector of $E$. canis and parasitism increases the possibility of infection of dogs.

\section{Conclusions}

In conclusion, the dogs of the municipality of Ituberá, Bahia, has high positivity for Ehrlichia spp. The analysis of the sensitivity and specificity of the diagnostic methods used in this study suggests that the complementary use of these tests will assist in the confirmation of Ehrlichia spp. exposure.

\section{References}

Aguiar DM, Cavalcante GT, Pinter A, Gennari SM, Camargo LMA, Labruna MB. Prevalence of Ehrlichia canis (Rickettsiales: Anaplasmataceae) in dogs and Rhipicephalus sanguineus (Acari: Ixodidae) ticks from Brazil. J Med Entomol 2007; 44(1): 126-132. http://dx.doi.org/10.1093/ jmedent/41.5.126. PMid:17294930

Al-Adhami B, Scandrett WB, Lobanov VA, Gajadhar AA. Serological cross-reactivity between Anaplasma marginale and an Ehrlichia species in naturally and experimentally infected cattle. J Vet Diagn Invest 2011; 23(6): 1181-1188. http://dx.doi.org/10.1177/1040638711425593. PMid:22362799

Albernaz AP, Miranda FJB, Melo OA Jr, Machado JA, Fajardo HV. Erliquiose canina em Campos dos Goytacazes, Rio de Janeiro, Brasil. Ciênc Anim Bras 2007; 8(4): 799-806.

Altman DG, Bland JM. Diagnostic tests. 1: Sensitivity and specificity. BMJ 1994; 308(6943): 1552. http://dx.doi.org/10.1136/bmj.308.6943.1552. PMid:8019315

André MR, Adania CH, Machado RZ, Allegretti SM, Felippe PAN, Silva KF, et al. Molecular and serologic detection of Ehrlichia spp. in endangered Brazilian wild captive felids. JWildl Dis 2010; 46(3): $1017-$ 1023. http://dx.doi.org/10.7589/0090-3558-46.3.1017. PMid:20688716

André MR, Baccarim Denardi NC, Marques de Sousa KC, Gonçalves LR, Henrique PC, Grosse Rossi Ontivero CR, et al. Arthropod-borne pathogens circulating in free-roaming domestic cats in a zoo environment in Brazil. Ticks Tick Borne Dis 2014; 5(5): 545-551. http://dx.doi. org/10.1016/j.ttbdis.2014.03.011. PMid:24889035

André MR, Dumler JS, Scorpio DG, Teixeira RH, Allegretti SM, Machado RZ. Molecular detection of tick-borne bacterial agents in Brazilian and exotic captive carnivores. Ticks Tick Borne Dis 2012; 3(4): 247-253. http:// dx.doi.org/10.1016/j.ttbdis.2012.04.002. PMid:22749737

Azevedo SS, Aguiar DM, Aquino SF, Orlandelli RC, Fernandes ARF, Uchôa ICP. Soroprevalência e fatores de risco associados à soropositividade 
para Ehrlichia canis em cães do semiárido da Paraíba. BrazJ Vet Res Anim Sci 2011; 48(1): 14-18.

Braga MS, André MR, Freschi CR, Teixeira MC, Machado RZ. Molecular and serological detection of Ehrlichia spp. in cats on São Luís Island, Maranhão, Brazil. Rev Bras Parasitol Vet 2012; 21(1):37-41. http://dx.doi. org/10.1590/S1984-29612012000100008. PMid:22534943

Carlos RSA, Carvalho FS, Wenceslau AA, Almosny NRP, Albuquerque GR. Risk factors and clinical disorders of canine ehrlichiosis in the South of Bahia, Brazil. Rev Bras Parasitol Vet 2011; 20(3): 210-214. http:// dx.doi.org/10.1590/S1984-29612011000300006. PMid:21961750

Carlos RSA, Muniz ES Na, Spagnol FH, Oliveira LL, Brito RL, Albuquerque GR, et al. Freqüência de anticorpos anti-Erhlichia canis, Borrelia burgdorferi e antígenos de Dirofilaria immitis em cães na microrregião Ilhéus-Itabuna, Bahia, Brasil. Rev Bras Parasitol Vet 2007; 16(3): 117-120. http://dx.doi. org/10.1590/S1984-29612007000300001. PMid:18078596

Carvalho FS, Wenceslau AA, Carlos RSA, Albuquerque GR. Epidemiological and molecular study of Ehrlichia canis in dogs in Bahia, Brazil. Genet Mol Res 2008; 7(3): 657-662. http://dx.doi.org/10.4238/vol7-3gmr468. PMid:18752193

Cifuentes E. Program for the elimination of urban rabies in Latin America. Rev Infect Dis 1988; 10(Suppl 4): S689-S692. http://dx.doi.org/10.1093/ clinids/10.Supplement_4.S689. PMid:3206081

Costa LM Jr, Rembeck K, Ribeiro MFB, Beelitz P, Pfister K, Passos LMF. Sero-prevalence and risk indicators for canine ehrlichiosis in three rural areas of Brazil. Vet J 2007; 174(3): 673-676. http://dx.doi.org/10.1016/j. tvjl.2006.11.002. PMid:17204439

Dagnone AS, Souza AI, André MR, Machado RZ. Molecular diagnosis of Anaplasmataceae organisms in dogs with clinical and microscopical signs of ehrlichiosis. Rev Bras Parasitol Vet 2009; 18(4): 20-25. http:// dx.doi.org/10.4322/rbpv.01804004. PMid:20040204

Dean AG, Arner T. Epi Info: Epidemiology of program office [online]. 2009 [cited 2013 Jan 20]. Available from: http://www.cdc.gov/epiinfo/ index.html.

Dean AG, Sullivan KM, Soe MM. OpenEpi: Open Source Epidemiologic Statistics for Public Health [online]. 2001 [cited 2013 Fev 15]. Available from: http://www.OpenEpi.com.

Dumler JS, Barbet AF, Bekker CP, Dasch GA, Palmer GH, Ray SC, et al. Reorganization of genera in the families Rickettsiaceae and Anaplasmataceae in the order Rickettsiales: unification of some species of Ehrlichia with Anaplasma, Cowdria with Ehrlichia and Ehrlichia with Neorickettsia, descriptions of six new species combinations and designation of Ehrlichia equi and 'HGE agent' as subjective synonyms of Ehrlichia phagocytophila. Int J Syst Evol Microbiol 2001; 51(Pt 6): 2145-2165. http://dx.doi. org/10.1099/00207713-51-6-2145. PMid:11760958

Faierstein CC, Silva EP, Febrônio AMB. Notas sobre a Erliquiose canina no município de Aracajú, Sergipe (2006- 2007). Biol Geral Exper 2008; $8(2): 5-7$.

Harrus S, Waner T. Diagnosis of canine monocytotropic ehrlichiosis (Ehrlichia canis): an overview. Vet J2011; 187(3): 292-296. http://dx.doi. org/10.1016/j.tvjl.2010.02.001. PMid:20226700

Harrus S, Waner T, Aizenberg I, Foley JE, Poland AM, Bark H. Amplification of ehrlichial DNA from dogs 34 months after infection with Ehrlichia canis. J Clin Microbiol 1998; 36(1): 73-76. PMid:9431923.

Iqbal Z, Chaichanasiriwithaya W, Rikihisa Y. Comparison of PCR with other tests for early diagnosis of canine ehrlichiosis. J Clin Microbiol 1994; 32(7): 1658-1662. PMid:7929754.
Krawczak FS, Labruna MB, Sangioni LA, Vogel FSF, Soares JF, Lopes STA. Serological survey on Ehrlichia sp. among dogs in the central region of Rio Grande do Sul. Rev Bras Parasitol Vet 2012; 21(4): 415-417. http:// dx.doi.org/10.1590/S1984-29612012005000001. PMid:23184320

Machado RZ, André MR, Werther K, de Sousa E, Gavioli FA, Alves JR Jr. Migratory and carnivorous birds in Brazil: reservoirs for Anaplasma and Ehrlichia species? Vector Borne Zoonotic Dis 2012; 12(8): 705-708. http://dx.doi.org/10.1089/vbz.2011.0803. PMid:22607070

Machado RZ, Duarte JMB, Dagnone AS, Szabó MP. Detection of Ehrlichia chaffeensis in Brazilian marsh deer (Blastocerus dichotomus). Vet Parasitol 2006; 139(1-3): 262-266. http://dx.doi.org/10.1016/j. vetpar.2006.02.038. PMid:16621285

Moreira SM, Bastos CV, Araújo RB, Santos M, Passos LMF. Retrospective study (1998-2001) on canine ehrlichiosis in Belo Horizonte, MG, Brazil. Arq Bras Med Vet Zootec 2003; 55(2): 141-147. http://dx.doi.org/10.1590/ S0102-09352003000200003.

Mundim ECS, Francisco MMS, Souza JN, Alencar MAG, Ramalho PCD. Incidência de hemoparasitoses em cáes (Canis familiares) de rua capturados pelo Centro de Controle de Zoonoses (CCZ) da cidade de Anápolis-GO. Ensaios e Cienc 2008; 12(2): 107-115.

Murphy GL, Ewing SA, Whitworth LC, Fox JC, Kocan AA. A molecular and serologic survey of Ehrlichia canis, E. chaffeensis, and E. ewingii in dogs and ticks from Oklahoma. Vet Parasitol 1998; 79(4): 325-339. http://dx.doi.org/10.1016/S0304-4017(98)00179-4. PMid:9831955

Nakaghi ACH, Machado RZ, Costa MT, André MR, Baldani CD. Erliquiose canina: aspectos clínicos, hematológicos, sorológicos e moleculares. Cienc Rural 2008; 38(3): 766-770. http://dx.doi.org/10.1590/ S0103-84782008000300027.

Perez M, Bodor M, Zhang C, Xiong Q, Rikihisa Y. Human infection with Ehrlichia canis accompanied by clinical signs in Venezuela. Ann N Y Acad Sci 2006; 1078(1): 110-117. http://dx.doi.org/10.1196/ annals.1374.016. PMid:17114689

Sacchi AB, Duarte JM, André MR, Machado RZ. Prevalence and molecular characterization of Anaplasmataceae agents in free-ranging Brazilian marsh deer (Blastocerus dichotomus). Comp Immunol Microbiol Infect Dis 2012; 35(4): 325-334. http://dx.doi.org/10.1016/j.cimid.2012.02.001. PMid:22381686

Sampaio IBM. Estatística aplicada à experimentação animal. Belo Horizonte: Fundaçáo de Ensino e Pesquisa em Medicina Veterinária e Zootecnia; 1998.

Schotthoefer AM, Meece JK, Ivacic LC, Bertz PD, Zhang K, Weiler T, et al. Comparison of a real-time PCR method with serology and blood smear analysis for diagnosis of human anaplasmosis: importance of infection time course for optimal test utilization. J Clin Microbiol 2013; 51(7): 2147-2153. http://dx.doi.org/10.1128/JCM.00347-13. PMid:23637292

Silva JN, Almeida AB, Boa Sorte EC, Freitas AG, Santos LGF, Aguiar $\mathrm{DM}$, et al. Soroprevalência de anticorpos anti-Ehrlichia canis em cães de Cuiabá, Mato Grosso. Rev Bras Parasitol Vet 2010; 19(2): 108-111. http://dx.doi.org/10.4322/rbpv.01902008. PMid:20624348

Souza BMPS, Leal DC, Barboza DCPM, Uzêda RS, Alcântara AC, Ferreira F, et al. Prevalência da infecção por Ehrlichia em cães e carrapatos no Nordeste do Brasil. Rev Bras Parasitol Vet 2010; 19(2): 89-93. http:// dx.doi.org/10.4322/rbpv.01902004. PMid:20624344

Stein A, Raoult D. A simple method for amplification of DNA from paraffin-embedded tissues. Nucleic Acids Res 1992; 20(19): 5237-5238. http://dx.doi.org/10.1093/nar/20.19.5237. PMid:1408846 
Suksawat J, Hegarty BC, Breitschwerdt EB. Seroprevalence of Ehrlichia canis, Ehrlichia equi, and Ehrlichia risticii in sick dogs from North Carolina and Virginia. J Vet Intern Med 2000; 14(1): 50-55. http:// dx.doi.org/10.1892/0891-6640(2000)014<0050:SOCEAR>2.3.CO;2. PMid:10668817

Trapp SM, Dagnone AS, Vidotto O, Freire RL, Amude AM, de Morais HS. Seroepidemiology of canine babesiosis and ehrlichiosis in a hospital population. Vet Parasitol 2006; 140(3-4): 223-230. http://dx.doi. org/10.1016/j.vetpar.2006.03.030. PMid:16647817
Vieira RFC, Biondo AW, Guimarães AM, Santos AP, Santos RP, Dutra LH, et al. Ehrlichiosis in Brazil. Rev Bras Parasitol Vet 2011; 20(1): 1-12. http://dx.doi.org/10.1590/S1984-29612011000100002. PMid:21439224

Waner T, Harrus S, Jongejan F, Bark H, Keysary A, Cornelissen AW. Significance of serological testing for ehrlichial diseases in dogs with special emphasis on the diagnosis of canine monocytic ehrlichiosis caused by Ehrlichia canis. Vet Parasitol 2001; 95(1): 1-15. http://dx.doi. org/10.1016/S0304-4017(00)00407-6. PMid:11163693 